\title{
Critics appeased by changes in UK national curriculum
}

London. Britain's scientific community has, in general, given a warm welcome to the government's announcement last week of plans to streamline the national curriculum. The result will be to reduce both the amount of material that school students are required to learn, and the time spent by teachers in evaluating their pupils.

But several bodies remain concerned that too many 14-16-year-olds will continue to take the controversial 'single award' science curriculum, which is taught in only 10 per cent of the curriculum time.

The revised curriculum was launched by Sir Ron Dearing, chairman of the School Curriculum and Assessment Authority (SCAA) and Mrs Gillian Shephard, the Secretary of State for Education, and followed a four-month consultation period after a draft version of the revisions was published in May.

The slimmed-down curriculum, with three core subjects, English, mathematics and science, covers 10 subjects in a total of 222 pages, compared to 330 in the original. And 1,000 'statements of attainment', heavily criticized by teachers as a 'tick-list' form of assessment, have been cut to 200 broad descriptions.

The changes in the science curriculum are based on 60,000 responses to the consultation document received by SCAA. They include an increase in the amount of chemistry in both the 13-14 and 14-16 age groups, and an overall reduction in the Earth science component.

Pupils at secondary schools (ages 1116) took integrated courses of 'balanced science' before the introduction of the national curriculum in 1988. But the spread of balanced science, initiated by the national curriculum, has been well received, not least because it has helped to increase the number of girls studying science past the age of 14 .

But there has been widespread concern about the 'single science' award for the 1416 age group, in which all three topics are covered in only 10 per cent of the curriculum time. Many scientific institutions argue that this is insufficient to give pupils the grounding they need to deal with issues in everyday life, and that the 'double science' award should be the minimum requirement (see Nature 370, 406; 1994).

"The proposals for double award science go a long way to restoring the balance of the major subjects and we therefore welcome the draft order," says Tony Ashmore, education secretary for the Royal Society of Chemistry. "But we remain concerned that too many young people might either choose or be forced into taking single award."

The society had hoped for some guidance on which pupils should be allowed to do single science. But the draft order does not provide any clarification. Dearing supports the government's view that "the great majority" of pupils - around 80 per cent should take double science. But he says that choosing who should do so is a matter of discretion "for the school, the parents and the children".

The changes to the single-science syllabus include the removal of the section on the physiology of green plants to be replaced by more on human nutrition and a "more overt reference" to living organisms in their natural environment.

In addition, the theoretical aspects of

\section{IMAGE UNAVAILABLE FOR COPYRIGHT REASONS}

\section{hter load: targets have been reduced}

structure and bonding of compounds in the 'materials and their properties' section have been replaced by work on patterns of behaviour and the periodic table.

But the Royal Society is still concerned. "They have revised it [single-award science] quite significantly, but it's still there and we're worried that pupils will still take it," says Robert Rees, education officer for the society.

The Association for Science Education (ASE) also welcomed the revisions to the national curriculum. But it called for a "more considered evaluation of the educational needs of children in the 21 st century and the role which science education has in this".

A particular target now is likely to be post-16 education. Dick West, professor of science education at the Open University and a former president of the ASE, points out that the system for 14-16 year olds is "totally decoupled" from the academic curriculum for 16-19 year olds.

West argues that Britain still needs to move to a broader baccalaureate-type system. Such an idea was proposed by the Royal Society in a report in 1991. "Now that the immediate panic over reforming the national curriculum is over, we will be revisiting post-16 education," says Rees.

Maggie Verral

\section{Maths minus boys means 'better learning for girls'}

Boston. Girls-only mathematics classes may soon be taught in a New Hampshire high school in an attempt to improve girls' examination performance. If the proposal, made by Charles Vaughn, a New Hampshire state representative, is adopted by the school board of Portsmouth High School, a girlsonly freshman algebra class will be offered next September. The board is due to vote on the issue in January or February.

Vaughn hopes that the initiative will help to narrow or eliminate the "achievement gap" between boys and girls on the Scholastic Assessment Test (SAT), the national examination taken by US high-school students. Studies have shown that boys attract more attention than girls in the classroom, and Vaughn thinks the relative success of boys may be attributable to this unintentional favouritism - a problem that could be avoided in all-girl classes.

Similar programmes already exist in Ventura, California and Presque Isle, Maine. But the idea is far from being universally accepted. Susan Foye, head of the mathematics department at Portsmouth High School, believes that creating a separate class for girls is unnecessary. "Just design classes in a manner that enables everyone, boys and girls, to thrive," Foye suggests.

Catherine Didion, executive director of the Association for Women in Science, based in Washington, DC, is also in favour of trying to improve mixed classes, although she admits that such improvement will take time to implement.

"In the meantime, why can't we teach an all-girl course and see what we learn from that?" asks Didion.

Steve Nadis

\section{AIDS 'czar' favours basic research}

Washington. President Bill Clinton has confirmed the appointment of Patsy Fleming as White House AIDS Policy Director. She has been filling the post on an interim basis since Clinton's first 'AIDS czar', Kristine Gebbie, resigned in August.

Fleming was formerly a congressional staffer active on AIDS issues and, more recently, a special assistant to Donna Shalala, the health secretary.

She has promised to help women and young people protect themselves from AIDS, and to work with William Paul, director of the recently strengthened office of AIDS Research at the National Institutes of Health, in his effort to concentrate on basic research aimed at understanding the nature of the disease.

Colin Macilwain 